\title{
Assessment of the effectiveness of differential management of patients in the early postoperative period following the dental implant surgery
}

\author{
Yu. Yu. Yarov \\ Donetsk National Medical University, Kramatorsk, Ukraine
}

Key words: dental implants, oral hygiene, differential treatment.

\section{Zaporozhye}

medical journal

2018; 20 (6), 832-836

DOl:

10.14739/2310-1210

2018.6.146756

E-mail:

Yarov.yuriy@gmail.com
Development of the modern dental implantology as a science is rapidly advancing, making impressive gains. Despite the undoubted achievements, an important issue of the dental implantation is the risk of inflammatory post-surgical complications.

Aim of the study. To assess the effectiveness of the proposed differential medicamentous therapy after dental implant surgery based on the results of clinical picture dynamic monitoring in the early postoperative period (up to 3 months).

Materials and methods. 124 somatically healthy people (54 men and 70 women) aged from 18 to 34 years were examined, among them: 25 patients with intact periodontium, 35 patients with chronic catarrhal gingivitis (CCG), 30 patients with generalized periodontitis (GP) of the initial, initial-I degrees of severity, 34 patients with GP of the I and III degree of severity. Patients were divided into 2 equal study groups: the proposed differential therapy was used for the experimental group (62 patients) in the early post-surgical period depending on the determined initial oral hygienic status; the traditional medicamentous treatment was applied for the control group (62 patients). Since the special medicamentous therapy was not advisable for the patients with healthy periodontium (25 patients) after the implant surgery, they made up the comparison group. Immunomodulating monotherapy (6 "Imudon" lozenges per day for 2 weeks) was prescribed to patients with CCG in the postoperative period. Immunomodulating therapy ("Imudon" by the same scheme) combined with a universal broad-spectrum antimicrobial drug "Miramistin" was prescribed to patients with GP of the initial, initial-I, I and I-II degrees of severity for 2 weeks. Control examinations were performed one week after removing the stitches, then weekly for 3 months before the second stage of surgery.

Results. One week after removing the stitches a significantly better oral hygienic status was observed in the main group of patients with CCG compared to the control $(P<0.05)$. When assessing the mucosa state above the intraosseous element in CCG patients, cases of peri-implantitis were detected neither in the main nor in the control group in the postoperative period. In the main group of patients with GP of the initial, initial-I degrees of severity the oral cavity hygienic status was significantly better in all periods of observation, starting from the first week after removing the stitches and after 3 months compared with the control $(P<0.05)$. When assessing the mucosa state above the intraosseous element in patients with GP of the initial, initial-I degree of severity in the postoperative period, one case of peri-implantitis was revealed in the control group. It manifested as hyperemia and edema of the mucosa above the intraosseous element during the 1 st week after removing the stitches and granulation tissue growth during the $2 n d$ week. The main group of patients with GP of the I, I-II degrees of severity were characterized by significantly better oral hygienic status -1.90 times on average $(P<0.05)$, compared with the control, from the 1 st week after removing the stitches and over the follow-up period up to 3 months. When assessing the mucosa state above the intraosseous element in patients with GP of the I, I-II degrees of severity in the postoperative period, one case of peri-implantitis was revealed in the control, similarly to patients with GP of the initial, initial-I degrees of severity.

Conclusions. Analysis of the clinical parameters dynamics in the patients after dental implant surgery suggests the effectiveness of the proposed methods in addition to the traditional maintenance therapy in the early period of 1 week after removing the stitches to 3 months. The obtained results allow to recommend the proposed methods of differential medicamentous therapy in the early postoperative period following the dental implant surgery for a wide application in dental practice.
Киючові слова:

Аентальна

імплантація,

гігієнічний стан,

Аиференційоване мікування.

Запорізький медичний журнал. - 2018. -

T. 20, № 6(111). C. 832-836

\section{Оцінювання ефективності диференційованого ведення хворих після операції дентальної імплантації в найближчі терміни}

\section{Ю. Ю. Яров}

Розвиток сучасної дентальної імплантології як науки відбувається стрімко, набуваючи масштабів, що вражають. Незважаючи на безсумнівні досягнення, важливою проблемою дентальної імплантації є ризик виникнення післяопераційних ускладнень запального характеру.

Мета роботи - оцінити ефективність запропонованої диференційованої медикаментозної терапії в післяопераційному періоді у хворих, яким проведена дентальна імплантація, за результатами динамічного спостереження за клінічною картиною в найближчі терміни до 3 місяців.

Матеріали та методи. Обстежили 124 соматично здорові людини (54 чоловіки та 70 жінок) віком від 18 до 34 років. Серед обстежених 25 осіб з інтактним пародонтом, 35 хворих на хронічний катаральний гінгівіт (ХКГ), 30 хворих на генералізований пародонтит (ГП) початкового-І, І ступеня, 34 хворих на ГП I, І-ІІ ступенів тяжкості. Пацієнтів поділили на 2 групи: дослідна (62 пацієнти), яка в ранньому післяопераційному періоді отримувала запропоновану медикаментозну терапію (обсяг визначався вихідним гігієнічним станом порожнини рота); контрольна (62 пацієнти), котра одержувала традиційне лікування. Оскільки пацієнтам зі здоровим пародонтом (25 осіб) недоцільно призначати спеціальну медикаментозну терапію після операції імплантації, вони склали групу порівняння. Хворим на ХКГ у післяопераційному періоді рекомендована монотерапія з застосуванням імуномодулювального препарату «Імудон» у вигляді пігулок для розсмоктування по 6 на день протягом 2 тижнів. Хворим із ГП початкового, початкового-І ступеня та I, I-II ступенів рекомендовано поєднане призначення імуномодулювального препарату «Імудон» у зазначеній схемі та універсального антимікробного препарату широкого спектра дії «Мірамістин» протягом 2 тижнів. Контрольні дослідження виконували через 1 тиждень після зняття швів, потім щотижня протягом 3 місяців до початку другого етапу операції. 
Результати. Через 1 тиждень після зняття швів визначили вірогідно кращий гігієнічний стан порожнини рота у хворих на ХКГ основної групи в порівнянні з контролем ( $p<0,05)$. Оцінюючи стан слизової оболонки над внутрішньокістковим елементом у хворих на ХКГ у післяопераційному періоді, не виявили жодного випадку периімплантиту ані в основній, ані в контрольній групі. У хворих на ГП початкового, початкового-І ступенів основної групи в усі терміни спостереження, починаючи з 1 тижня після зняття швів і через 3 місяці, встановили вірогідно кращий гігієнічний стан порожнини рота порівняно 3 контролем $(p<0,05)$. Оцінюючи стан слизової оболонки над внутрішньокістковим елементом у хворих на ГП початкового, початкового-І ступенів у післяопераційному періоді в контролі виявили один випадок периімплантиту, який на 1 тижні після зняття швів спостерігали як гіперемію та набряк слизової оболонки над внутрішньокістковим елементом, а на 2 тижні як грануляції. У хворих на ГП I, I-II ступенів основної групи, починаючи 31 тижня після зняття швів і в усі наступні терміни спостереження до 3 місяців, виявили вірогідно кращий гігієнічний стан порожнини рота порівняно з контролем у середньому в 1,9 раза $(p<0,05)$. Оцінюючи стан слизової оболонки над внутрішньокістковим елементом у хворих на ГП I, І-ІІ ступенів у післяопераційному періоді, в контролі виявили, як і у хворих на ГП початкового, початкового-І ступенів, один випадок периімплантиту.

Висновки. Аналіз динаміки клінічних показників у хворих після дентальної імплантації свідчить про ефективність запропонованих методів додатково до традиційної підтримувальної терапії в найближчі терміни (від 1 тижня після зняття швів) до 3 місяців. Результати дають змогу рекомендувати запропоновані методи медикаментозного лікування в ранньому післяопераційному періоді після дентальної імплантації для широкого застосування у практичній стоматології.

\section{Оценка эффективности дифференцированного медикаментозного ведения больных после операции дентальной имплантации в ближайшие сроки}

\section{Ю. Ю. Яров}

Развитие современной дентальной имплантологии как науки происходит стремительно, приобретая впечатляющие масштабы. Несмотря на несомненные достижения, важной проблемой дентальной имплантации остается риск возникновения послеоперационных осложнений воспалительного характера.

Цель работы - оценка эффективности предложенной дифференцированной медикаментозной терапии в послеоперационном периоде у больных, которым была проведена дентальная имплантация, по результатам динамического наблюдения за клинической картиной в ближайшие сроки до 3 месяцев.

Материалы и методы. Обследовали 124 соматически здоровых человека (54 мужчины и 70 женщин) в возрасте от 18 до 34 лет. Среди них 25 человек с интактным пародонтом, 35 больных хроническим катаральным гингивитом (ХКГ), 30 больных генерализованным пародонтитом (ГП) начальной-І, I степени, 34 больных ГП I, І-ІІ степеней тяжести. Пациентов поделили на 2 группы: опытная (62 человека), которая в раннем послеоперационном периоде получала предложенную медикаментозную терапию (объем определялся исходным гигиеническим состоянием полости рта); контрольная (62 человека), которая получала традиционную терапию. Поскольку пациентам со здоровым пародонтом (25 человек) нецелесообразно проводить специальную медикаментозную терапию после операции имплантации, они составили группу сравнения. Больным ХКГ в послеоперационном периоде рекомендована монотерапия с применением иммуномодулирующего препарата «Имудон» в виде таблеток для рассасывания по 6 таблеток в день в течение 2 недель. Больным ГП начальной, начальной-І степени и I, I-II степени рекомендовано сочетанное назначение иммуномодулирующего препарата «Имудон» в указанной схеме и универсального антимикробного препарата широкого спектра действия «Мирамистин» в течение 2 недель. Контрольные исследования проводили через 1 неделю после снятия швов, затем еженедельно в течение 3 месяцев до начала второго этапа операции.

Результаты. Через 1 неделю после снятия швов отмечено достоверно лучшее гигиеническое состояние полости рта у больных ХКГ основной группы по сравнению с контролем $(p<0,05)$. При оценке состояния слизистой оболочки над внутрикостным элементом у больных ХКГ в послеоперационном периоде не отмечено ни одного случая периимплантита ни в основной, ни в контрольной группе. У больных ГП начальной, начальной-І степени основной группы во все сроки наблюдения, начиная с 1 недели после снятия швов и спустя 3 месяца, отмечается достоверно лучшее гигиеническое состояние полости рта по сравнению с контролем ( $<$ 0,05). При оценке состояния слизистой оболочки над внутрикостным элементом у больных ГП начальной, начальной-І степени в послеоперационном периоде в контроле отмечен один случай периимплантита, который на 1 неделе после снятия швов проявлялся в виде гиперемии и отечности слизистой оболочки над внутрикостным элементом, а на 2 - появлением грануляций. У больных ГП I, І-ІІ степени основной группы, начиная с 1 недели после снятия швов и во все последующие сроки наблюдения до 3 месяцев, отмечено достоверно лучшее гигиеническое состояние полости рта по сравнению с контролем в среднем в 1,9 раза $(p<0,05)$. При оценке состояния слизистой оболочки над внутрикостным элементом у больных ГП I, I-ІІ степени в послеоперационном периоде в контроле отмечен, как и у больных ГП начальной, начальной-І степени, один случай периимплантита.

Вывод. Анализ динамики клинических показателей у больных после дентальной имплантации свидетельствует об эффективности предложенных методов дополнительно к традиционной поддерживающей терапии с ближайшие сроки от 1 недели после снятия швов до 3 месяцев. Результаты позволяют рекомендовать предложенные методы медикаментозного лечения в раннем послеоперационном периоде после дентальной имплантации для широкого применения в практической стоматологии.

Development of the modern dental implantology as a science is rapidly advancing, making impressive gains [1-2]. Despite the undoubted achievements, an important issue of the dental implantation is the risk of inflammatory post-surgical complications [3-6].
Implantation belongs to the clean-contaminated surgery. The biofilm role increases significantly in the postoperative period and could be a decisive factor for dental implant failure [7-9]. That is why the issue of hygienic status of patients before and after implantation deserves special
Ключевые слова: Аентальная имплантация, гигиеническое состояние, Аифференцированное лечение.

Запорожский медицинский журнал. - 2018. T. 20, № 6(111). C. $832-836$ 
attention. However, there is a risk of microbial invasion, which could be a potential threat to the treatment of patients with dental implants $[10,11]$. Pathogenic and conditionally pathogenic microflora can cause a chronic inflammatory process, progressing from soft tissues to the bone and leading to its rapid resorption. Following that, the further implants functioning becomes impossible, which is clinically confirmed - approximately in $30 \%$ of patients diagnosed with peri-implantitis such picture can be observed $[12,13]$.

\section{Purpose}

Purpose of this study was to assess the effectiveness of the proposed differential medicamentous therapy after dental implant surgery based on a dynamic monitoring of the clinical picture in the early postoperative period (up to 3 months).

\section{Materials and methods}

124 somatically healthy people (54 men and 70 women) aged from 18 to 34 years old were examined, among them: 25 patients with intact periodontium, 35 patients with chronic catarrhal gingivitis (CCG), 30 patients with generalized periodontitis (GP) of the initial-I, I degrees, 34 patients with GP I, I-II degrees of severity. Diagnosis of CCG and GP was based on the clinical examination, radiography, periodontal indices and tests, in accordance with the classification of periodontal diseases by N. F. Danilevsky (1994). For the purpose of an objective oral hygiene assessment, the total oral hygiene Green-Vermilion's Index (OHI-S) (Green, Vermillion, 1960) was determined, taking into account the plaque and debris components (score 0-3, total score 0-6).

Clinical and X-ray examination and complex treatment of patients, including dental implantation, were provided on the basis of the "University Clinic" (2012-2014) and the Department of Dentistry No. 2 (2017-2019) of the Donetsk National Medical University and on the basis of the Department of Dentistry of Postgraduate Education at the Higher State Educational Establishment "Ukrainian Medical Stomatological Academy" (2015-1016).

Prior to the dental implant surgery, all patients underwent the oral cavity sanation and professional dental cleaning. Patients diagnosed with CCG and GP received a complex treatment in accordance with the "Protocols of dental treatment" (Order of the MoH of Ukraine No. 566 dated 23 November, 2004).

Edentulism was corrected with intraosseous screw implants. The surgery was performed using two-stage procedure. At the first stage, implants were installed with subsequent suturing of the mucous membrane: on the upper jaw - for 3 months, on the lower - for 6 months. After removal of the stitches, weekly examinations were carried out for 3 months. At the same time, attention was paid to the condition of the mucous membrane covering the intraosseous elements of the implants because during this period the most characteristic complications in the form of peri-implantitis and dental implant failure can be observed. The clinical picture of peri-implantitis in the region of the intraosseous element placement during the first stage is characterized by the local edema and hyperemia, fistula, or granulation tissue on the mucosa covering the intraosseous element (in 2-3 weeks). In contrast with peri-implantitis, dental implant failure is an inflammatory process that begins in the surrounding bone. The clinical picture of this variant of dental implant failure is characterized by hyperemia, edema, fistula over the intraosseous element (after 2-3 weeks).

Patients were divided into 2 equal study groups: the proposed differential therapy was used for the experimental group (62 patients) in the early post-surgical period depending on the determined initial oral hygienic status; the traditional medicamentous treatment was applied for the control group (62 patients). Since the special medicamentous therapy was not advisable for the patients with healthy periodontium ( 25 patients) after the implant surgery, they made up the comparison group.

Immunomodulating monotherapy (6 "Imudon" lozenges per day for 2 weeks) was prescribed to patients with CCG and unsatisfactory hygienic status in the postoperative period. Immunomodulating therapy ("Imudon" by the same scheme) combined with a universal broad-spectrum antimicrobial drug "Miramistin" was prescribed to patients with GP of the initial, initial-I, I and I-II degrees of severity for 2 weeks. Control examinations were performed one week after removing the stitches, then weekly for 3 months before the second stage of surgery.

The obtained digital data were processed by variation statistics analysis on an IBM PC using standard Microsoft Excel software.

The average arithmetic mean (M), the standard deviation $(S)$, standard error of the mean value $(m)$ were calculated for each sample group of observation. Student's $\mathrm{t}$-criterion was used for comparison of means. The result was considered statistically significant when the 3-value was less than 0.05 .

\section{Results}

As can be seen from Table 1, a significantly better oral hygienic status was observed in the main group of patients with CCG compared to the control $(P<0.05) 1$ week after removing the stitches. In this case, the Green-Vermilion's $\mathrm{OHI}$ was on average 1.32 times lower in the main group in comparison with the control. Such difference remained over the follow-up period. It should be noted, that the level of oral hygiene in patients who received the proposed treatment with "Imudon" was the same as that in individuals with healthy periodontium in this period. When assessing the mucosa state above the intraosseous element in CCG patients, cases of peri-implantitis were detected neither in the main nor in the control group in the postoperative period.

In the main group of patients with GP of the initial, initial-I degrees of severity the oral cavity hygienic status was significantly better in all periods of observation, starting from the first week after removing the stitches and after 3 months compared with the control $(P<0.05)$. Green-Vermilion's $\mathrm{OHI}$ was in the range from $1.48 \pm 0.24$ to $1.59 \pm 0.24$ points in the main group, and it was on average 1.58 times lower in comparison with the control. It is worth mentioning that the level of hygiene in patients who received the proposed immunomodulatory drug "Imudon" in combination with the universal broad-spectrum antimicrobial drug "Miramistin" was the same as that in individuals with healthy periodontium in this period. 
Table 1. Dynamics of the Green-Vermillion's Hygienic Index in the patients with chronic catarrhal gingivitis after dental implant surgery

\begin{tabular}{l|l|l|l|l|l}
\hline & $\begin{array}{l}\text { The } 1^{\text {st }} \text { week } \\
\text { after removal of stitches }\end{array}$ & $\begin{array}{l}\text { The } 2^{\text {nd }} \text { week } \\
\text { after removal of stitches }\end{array}$ & $\begin{array}{l}\text { The } 3^{\mathrm{d}} \text { week } \\
\text { after removal of stitches }\end{array}$ & $\begin{array}{l}\mathbf{2} \text { months } \\
\text { after removal of stitches }\end{array}$ \\
$\begin{array}{lllll}\mathbf{3} \text { months } \\
\text { after removal of stitches }\end{array}$ \\
\hline Main group $(n=18)$ & $1.58 \pm 0.26^{*}$ & $1.52 \pm 0.25^{*}$ & $1.54 \pm 0.27^{*}$ & $1.48 \pm 0.24^{*}$ \\
Control $(n=17)$ & $2.18 \pm 0.36^{\wedge}$ & $2.12 \pm 0.29^{\wedge}$ & $1.92 \pm 0.26^{\wedge}$ & $1.89 \pm 0.23^{\wedge}$ \\
Comparison group $(n=25)$ & $1.46 \pm 0.16$ & $1.40 \pm 0.15$ & $1.38 \pm 0.14$ & $1.41 \pm 0.18$ \\
\hline
\end{tabular}

*: $\mathrm{P}<0.05$ - in comparison with the control; $\wedge$ : $\mathrm{P}<0.05$ - relative to the comparison group.

Table 2. Dynamics of the Green-Vermillion's Hygienic Index in the patients with chronic generalized periodontitis of the initial-I and I degrees of severity after dental implant surgery $(\mathrm{M} \pm \mathrm{m})$

\begin{tabular}{|c|c|c|c|c|c|}
\hline & $\begin{array}{l}\text { The } 1^{\text {st }} \text { week after } \\
\text { removal of stitches }\end{array}$ & $\begin{array}{l}\text { The } 2^{\text {nd }} \text { week after } \\
\text { removal of stitches }\end{array}$ & $\begin{array}{l}\text { The } 3^{\mathrm{d}} \text { week after } \\
\text { removal of stitches }\end{array}$ & $\begin{array}{l}2 \text { months after removal of } \\
\text { stitches }\end{array}$ & $\begin{array}{l}3 \text { months after removal of } \\
\text { stitches }\end{array}$ \\
\hline Main group $(n=15)$ & $1.59 \pm 0.24^{*}$ & $1.54 \pm 0.22^{*}$ & $1.52 \pm 0.25^{\star}$ & $1.48 \pm 0.24^{*}$ & $1.49 \pm 0.23^{*}$ \\
\hline Control $(n=15)$ & $2.48 \pm 0.26^{\wedge}$ & $2.42 \pm 0.24^{\wedge}$ & $2.38 \pm 0.25^{\wedge}$ & $2.39 \pm 0.23^{\wedge}$ & $2.36 \pm 0.25^{\wedge}$ \\
\hline Comparison group $(n=25)$ & $1.46 \pm 0.16$ & $1.40 \pm 0.15$ & $1.38 \pm 0.14$ & $1.41 \pm 0.18$ & $1.39 \pm 0.14$ \\
\hline
\end{tabular}

*: $\mathrm{P}<0.05$ - in comparison with the control; $\wedge$ : $\mathrm{P}<0.05$ - relative to the comparison group.

Table 3. Dynamics of the Green-Vermillion's OHI in the patients with chronic generalized periodontitis of the I, I-II degrees of severity after dental implant surgery $(\mathrm{M} \pm \mathrm{m})$

\begin{tabular}{l|l|l|l|l|l}
\hline & $\begin{array}{l}\text { The } 1^{\text {st }} \text { week after } \\
\text { removal of stitches }\end{array}$ & $\begin{array}{l}\text { The } 2^{\text {nd }} \text { week after } \\
\text { removal of stitches }\end{array}$ & $\begin{array}{l}\text { The } 3^{\mathrm{d}} \text { week after removal } \\
\text { of stitches }\end{array}$ & $\begin{array}{l}\text { 2 months after removal of } \\
\text { stitches }\end{array}$ & $\begin{array}{l}\mathbf{3} \text { months after removal of } \\
\text { stitches }\end{array}$ \\
\hline Main group $(n=17)$ & $1.60 \pm 0.26^{*}$ & $1.56 \pm 0.24^{*}$ & $1.52 \pm 0.25^{\star}$ & $1.47 \pm 0.23^{*}$ \\
\hline Control $(n=17)$ & $2.98 \pm 0.34^{\wedge}$ & $2.92 \pm 0.32^{\wedge}$ & $2.88 \pm 0.30^{\wedge}$ & $2.89 \pm 0.33^{\wedge}$ \\
\hline Comparison group $(n=25)$ & $1.46 \pm 0.16$ & $1.40 \pm 0.15$ & $1.38 \pm 0.14$ & $1.41 \pm 0.18$ \\
\hline
\end{tabular}

*: $\mathrm{P}<0.05$ - in comparison with the control; ^: $\mathrm{P}<0.05$ - relative to the comparison group.

The values of Green-Vermilion's $\mathrm{OHI}$ in the main and comparison groups reflect the average level of oral hygiene in patients in the early period after the dental implant surgery. When assessing the mucosa state above the intraosseous element in patients with GP of the initial, initial-I degrees of severity in the postoperative period, one case of peri-implantitis was revealed in the control group. It manifested as hyperemia and edema of the mucosa above the intraosseous element during the 1st week after removing the stitches and granulation tissue growth during the 2nd week (Table 2).

As can be seen from Table 3, the main group of patients with GP of the I, I-II degrees of severity were characterized by significantly better oral hygienic status -1.90 times on average $(P<0.05)$, compared with the control, from the 1st week after removing the stitches and over the follow-up period up to 3 months. In this case, the Green-Vermilion's $\mathrm{OHI}$ was in the range from $1.47 \pm 0.23$ to $1.60 \pm 0.26$ points (average hygiene level) in the main group, and from $2.86 \pm 0.29$ to $2.98 \pm 0.34$ points (very poor hygiene level) in the control group. It should be noted that the level of hygiene in patients who received the proposed immunomodulatory drug "Imudon" in combination with the universal broad-spectrum antimicrobial drug "Miramistin" was the same as that in individuals with healthy periodontium in this period, i.e. it was of average level and reached, on average, $1.53 \pm 0.24$ points. When assessing the mucosa state above the intraosseous element in patients with GP of the I, I-II degrees of severity in the postoperative period, one case of peri-implantitis was revealed in the control, similarly to patients with GP of the initial, initial-I degrees of severity, which manifested as hyperemia and edema of the mucosa above the intraosseous element during the 1 st week after removing the stitches and granulation tissue growth during the 2nd week.

\section{Discussion}

The obtained results confirm our concept of expediency of taking into account the initial level of the oral hygienic status in the management of patients in the postoperative period. Despite the fact that modern medicine has in its arsenal a sufficient number of methods of rehabilitation after dental implantation [13], effective methods of laser therapy are limited in application due to the lack of clear recommendations on the choice of exposure parameters [14]. Methods of protein-mineral metabolism correction, which include calcium-containing drugs, antiresorbers, stimulators of bone tissue formation, are mainly indicated in a long-term period after implantation and do not affect the level of oral cavity hygienic status [15]. The local and systemic immunity normalizing drugs are recommended for the management of patients with primary or secondary peri-implantitis in the postoperative period. The large number of scientific studies, focused on the essential role of oral hygiene after dental implantation, is increasingly convincing that even perfect oral hygiene is not enough to prevent the biofilms formation, and hence complications.

\section{Conclusions}

1. Analysis of the clinical indices dynamics in patients with chronic catarrhal gingivitis after dental implant surgery suggests the effectiveness of the proposed monotherapy with "Imudon" in addition to the traditional maintenance therapy in the early period of 1 week after removal of the stitches and up to 3 months.

2. Analysis of the clinical indices dynamics in patients with GP of the initial, initial-I degrees of severity after dental implant surgery suggests the effectiveness of the proposed 
combined therapy with "Imudon" and "Miramistin" in addition to the traditional maintenance therapy in the early period of 1 week after removal of the stitches and up to 3 months.

3. Analysis of the clinical indices dynamics in patients with GP of the I, I-II degrees of severity after dental implant surgery suggests the effectiveness of the proposed combined therapy with "Imudon" and "Miramistin" in addition to the traditional maintenance therapy in the early period of 1 week after removal of the stitches and up to 3 months.

The obtained results allow to recommend the proposed methods of differential medicamentous therapy in the early postoperative period following the dental implant surgery for a wide application in dental practice.

Due to the progressive development of implantology nowadays, these studies are promising. With an increase in the number of dental implant surgeries, an increase in the number of complications is observed, which requires further study of this issue.

Conflicts of interest: author has no conflict of interest to declare. Конфлікт інтересів: віАсутній.

Information about the author:

Yarov Yu. Yu., MD, Assistant of the Department of Stomatology No. 2, Donetsk National Medical University, Kramatorsk, Ukraine.

Відомості про автора:

Яров Ю. Ю., асистент каф. стоматології № 2, Аонецький національний медичний університет, м. Краматорськ, Україна.

Сведения об авторе:

Яров Ю. Ю., ассистент каф. стоматологии № 2, Аонецкий

национальный меАицинский университет, г. Краматорск, Украина.

Надійшла Ао редакції / Received: 10.01.2018

Після Аоопрацювання / Revised: 13.03.2018

Прийнято Ао Аруку / Accepted: 16.03.2018

\section{References}

[1] Blok, M. S. (2015) Dental'naya implantologiya. Hirurgicheskie aspekty [Dental implantology. Surgical aspects]. Moscow: MEDpress-inform. [in Russian].

[2] Smektala, T. Tutak, M. Endzheievski, M. \& Sporniak-Tutak, L. (2014) Biolohichni osnovy osteointehratsii [Biological bases of osteointegration]. Magazyn Stomatologiczy, 3, 68-72 [in Ukrainian].

[3] Andriasyan, L. G. \& Daburyan, P. A. (2015). E'pidemiologiya periimplantitov (obzor literaturnykh dannykh poslednikh let) [Epidemiology of peri-implantitis (review of literary data of recent years)]. Vestnik stomatologii i chelyustno-licevoj khirurgii, 3-4, 4-7 [in Russian].

[4] Leus, P. A., \& Fridberg, A. (2014) Teoretychne obhruntuvannia praktychni mozhlyvosti profilaktyky periimplantytu [Theoretical substantiation and practical possibilities of preventive maintenance of a periimplant]. Implantolohiia Parodontolohiia Osteolohiia, 2, 77-83. [in Ukrainian].

[5] Franke, M., Titman, K., \& Brozelier, F. (2013) Periimplantyt - novyi vyklyk. Diahnostyka, preventyvni stratehii ta kontrolni ohliady [Periimplant is a new challenge. Diagnostics, Preventive Strategies and Controls] Parodontologie, 24(1), 69-75. [in Ukrainian].

[6] Korsch, M., Obst, U., \& Walther, W. (2014) Cement-associated peri-implantitis: a retrospective clinical observational study of fixed implant-supported restorations using a methacrylate cement. Clin Oral Implants Res., 25(7), 797-802. doi: 10.1111/clr.12173.

[7] Koutouzis, T., Wallet, S., Calderon, N., \& Lundgren, T. (2011) Bacterial colonization of the implant-abutment interface using an in vitro dynamic loading model. J Periodontol, 82(4), 613-8. doi: 10.1902 jop.2010.100415
[8] Majkl, S. B. (2015) Dental'naya implantologiya. Khirurgicheskie aspekty [Dental implantology. Surgical aspects]. Moscow: Medpress-inform.

[9] Nayak, A. G., Fernandes, A., Kulkarni, R., Ajantha, G. S., Lekha, K., \& Nadiger, R. (2014) Efficacy of antibacterial sealing gel and O-ring to prevent microleakage at the implant abutment interface: an in vitro study. J Oral Implantol., 40(1), 11-4. doi: 10.1563/AAID-JOI-D-10-00167.

[10] Mehta, A., Shukla, R., \& Sodhi, S. P. S. (2014) Healing after gingivectomy by electrosurgery \& periodontal knives. Moscow: Lap lambert academic publishing.

[11] Kalmin, O. V., \& Fedorova, M. G. (2013) Morfologicheskie izmeneniya tkanej v zone implantacii. Moscow: Lap lambert academic publishing

[12] D’Ercole, S., Scarano, A., Perrotti, V., Mulatinho, J., Piattelli, A., lezzi, G. \& Tripodi, D. J. (2011) Implants with external hexagon and conica implant-abutment connections: An in vitro study of the bacterial contamination. Oral Implantol, 40(1), 30-6. doi: 10.1563/AAID-JOI-D-11-00121

[13] Samoilenko, I. A. (2016) Reabilitatsiini zakhody, taktyka antyoksydantnoi ta imunokorehuiuchoi terapii pry dentalnii implantatsii u khvorykh na heneralizovanyi parodontyt (Avtoref. dis...kand. med. nauk). [Rehabilitation measures, tactics of antioxidant and immunocorrective therapy for dental implantation in patients with generalized periodontitis]. (Extended abstract of candidate's thesis). Poltava. [in Ukrainian].

[14] Nechaeva, N. K. (2016) Konusno-luchevaya tomografiya $v$ dental'noj implantologii [Cone-ray tomography in dental implantology]. Moscow: GEOTAR-Media. [in Russian].

[15] Kaushal, S. \& Pal, A. S. (2014) Dental Implants and its design. Moscow: LAP Lambert Academic Publishing. 